\title{
DYPLOMATYCZNE DZIAŁANIA PAŃSTWA KATAR W ROZWIĄZYWANIU SPORÓW I KONFLIKTÓW NA BLISKIM WSCHODZIE I W AFRYCE
}

Celem artykułu jest ukazanie dyplomatycznych działań ze strony Państwa Katar (dalej także - Katar), które na przestrzeni wielu lat pozytywnie wpłynęły na wykreowanie nowej roli tego podmiotu jako głównego mediatora w rozwiązywaniu sporów i konfliktów międzynarodowych $\mathrm{w}$ regionie Bliskiego Wschodu, a także i w Afryce. Analizie poddano wybrane przykłady konfliktów, w których zostały zaprezentowane przyczyny, okoliczności i rezultaty zaangażowania się Kataru w ich rozwiązywanie. Główną tezą niniejszego artykułu jest twierdzenie, iż w wyniku szeroko zakrojonych działań dyplomatycznych w XXI wieku, Państwo Katar znacznie wzmocniło swoją pozycję międzynarodową w sferze politycznej, w tym w zakresie swojego bezpieczeństwa. Do tezy postawiono następujące pytania badawcze: (1) Z jakich powodów zwaśnione strony decydowały się na mediację katarską?; (2) Jak można ocenić i scharakteryzować mediacje prowadzone przez Katar?; (3) Jakie miejsce zajmuje mediacja w strategii polityki zagranicznej Kataru? Weryfikacja postawionej tezy i odpowiedź na powyższe pytania badawcze pomoże w wyjaśnieniu fenomenu w polityce międzynarodowej XXI wieku, jakim bez wątpienia jest aktywność dyplomatyczna Państwa Katar.

\section{AKTUALNY STAN BADAŃ}

W polskiej literaturze przedmiotu z zakresu nauk o polityce, państwu Katar nie poświęcano dotychczas zbyt wiele miejsca. W zasadzie ukazała się tylko jedna praca zbiorowa zatytułowana: Państwo Katar. Gospodarka - polityka-kultura, pod redakcja Katarzyny Górak-Sosnowskiej i Roberta Czuldy (Łódź 2009). Publikacja ta zawiera artykuły poświęcone zagadnieniom gospodarczym, politycznym, społecznym i kulturowym. Autorami prac są badacze polscy i zagraniczni ${ }^{1}$. Problematyka związana z po-

1 W sekcji ,polityka” na uwage zasługują teksty Johna E. Petersona Katar i świat. Budowanie marki mikropaństwa (thumaczenie artykułu Qatar and the World: Branding for a Micro-State, który ukazał się w „Middle East Journal” 2006, Vol. 60, No. 4); Stevena Wrighta Polityka zagraniczna Kataru: geopolityka i filary strategiczne; Davida B. Robertsa Katar w poszukiwaniu bezpieczeństwa. Ponadto znajdują się tu teksty Polityka wojskowa Kataru Roberta Czuldy i Stosunki Kataru ze Stanami Zjednoczonymi Stevena Ekovicha. Spośród artykułów poświęconych Państwu Katar należy wymieć: tekst Marcina Pietrzyka: Fenomen „Al-Dżaziry”, w: Arabowie-Islam-Świat, (red.) M. M. Dziekan, I. Kończak, Łódź 2007, w którym autor zobrazował tę stację telewizyjną jako instrument w polityce władcy Kataru; artykuł Roberta Czuldy: Priorytety bezpieczeństwa Kataru, który ukazał się w pokon- 
lityką zagraniczną i wewnętrzną Kataru w badaniach polskich autorów pojawiała się przy okazji opracowań poświęconych regionowi Bliskiego Wschodu, światowi arabskiemu czy przede wszystkim subregionowi Zatoki Perskiej. Do ważniejszych monografii w tym zakresie należą: Historia współczesna świata arabskiego Danuty Madeyskiej (Warszawa 2008); Polityka naftowa państw arabskich Zatoki Perskiej Blanki Łęgowskiej (Łódź 2007); czy Historia Arabii Wschodniej Jerzego Zdanowskiego (Warszawa 2008). W literaturze anglojęzycznej publikacji poświęconych polityce Państwa Katar jest znacznie więcej. Wśród tylko najnowszych monografii można wymienić: Allena J. Fromherza: Qatar: A Modern History (Padstow 2012); Matthew Gray'a: Qatar: Politics and the Challenges of Development (2013); Mehrana Kamravy: Qatar: Small State, Big Politics (New York 2013). W odniesieniu do artykułów, które w szczególności dotyczą polityki zagranicznej Kataru, a w tym jego działań dyplomatycznych na arenie międzynarodowej należy szczególnie wyróżnić tekst M. Kamravy: Mediation and Qatari Foreign Policy („Middle East Journal” 2011, Vol. 65, No. 4); artykuł Davida B. Robertsa Qatari Mediation (dostępny na internetowym portalu academia.edu) oraz tekst Liny Khatib Qatar's Foreign Policy: the limits of pragmatism („International Journal” 2013, Vol. 89, No. 2). Wszystkie te teksty wnoszą duży wkład w badania nad polityką zagraniczną Kataru i strategią działania tego państwa na arenie międzynarodowej. O ile publikacja L. Khatib stanowi analizę polityki zagranicznej Kataru jej mechanizmów, celów i przedstawienia specyficznych stosunków w Arabią Saudyjską, o tyle artykuły M. Kamravy i D. B. Robertsa odwołują się przede wszystkim do działań stricte dyplomatycznych prowadzonych przez katarski emirat. M. Kamrava opisał przykłady mediacji Kataru i ukazał je w kontekście zmian politycznych w tym kraju, jak i na arenie międzynarodowej w XXI wieku oraz dokonał analizy mechanizmów katarskich mediacji, które determinowały sukces dyplomacji tego emiratu. Artykuł D. B. Robertsa, chociaż stanowi nieprzygotowaną od strony technicznej wersję do druku, to pod względem merytorycznym jest bardzo rzetelną analizą przyczyn zaawansowanych działan dyplomatycznych ze strony Kataru, sposobu ich przeprowadzania i ich efektów.

\section{MEDIACJA JAKO DYPLOMATYCZNY SPOSÓB ROZWIĄZYWANIA SPORÓW MIĘDZYNARODOWYCH. ZAGADNIENIA TEORETYCZNE}

Pojęcie mediacji bezpośrednio wiąże się z zaistniałym sporem lub konfliktem. Zatem na wstępie należy wyjaśnić znaczenie obydwu tych terminów, które nie są tożsame. Sporem możemy nazywać „sytuację, w której cele i interesy dwóch stron są wyraźnie przeciwstawne”. Jest to dość często przytaczana w literaturze stosunków międzynarodowych definicja. Została ona zawarta w opinii doradczej Międzynarodowego Trybunału Sprawiedliwości (MTS) z 1950 r. (Bierzanek, Symonides, 2004: 339).

ferencyjnej pracy zbiorowej Świat arabski. Kultura i polityka, (red.) K. Pachniak, E. Machut-Mendecka, Warszawa 2012; artykuł Rafała Ożarowskiego: Mediacja Państwa Katar w libańskim sporze politycznym w 2008 roku, „Cywilizacja i Polityka” 2013, który stanowił pierwotną inspirację do przygotowania niniejszego tekstu, aby ukazać kompleksowe działania dyplomatyczne katarskiej monarchii. 
Konflikt z reguły jest określany jako ostrzejsza forma sporu, w której następuje eskalacja żądań i nasilenie się gróźb. Istnieje przy tym ryzyko użycia siły zbrojnej. Kiedy siła ta została użyta można mówić o konflikcie zbrojnym (Pawłowski, 2006: 351; Zenderowski, 2006: 471-472).

W literaturze akademickiej z zakresu prawa międzynarodowego i stosunków międzynarodowych dyplomatyczne sposoby rozwiązywania sporów międzynarodowych dzielą się na rokowania, dobre usługi i mediację, komisje badań i koncyliację. Mediacja jest ujmowana razem $z$ dobrymi usługami bowiem jeden, jak i drugi sposób ma na celu nakłonienie stron zwaśnionych do przystapienia do rokowań (Bierzanek, Symonides, 2004: 346). Przy dobrych usługach podmiot trzeci nie bierze bezpośredniego udziału w rokowaniach, a jedynie ułatwia stronom sporu nawiązanie rokowań bezpośrednich (Góralczyk, Sawicki, 2009: 384-385), zaś przy mediacji (określanej również jako pośrednictwo) mediator bierze udział w rokowaniach, podczas których może przedstawiać propozycje rozwiązania sporu (Bierzanek, 1994: 318). Udział mediatora ${ }^{2}$ jest zdecydowanie bardziej zaawansowany niż strony, która oferuje dobre usługi, chociaż nie brak opinii, że granica pomiędzy dobrymi usługami i mediacją jest nieostra, choćby ze względu na to, że trzecia strona najpierw może doprowadzić do rozpoczęcia rokowań pomiędzy zwaśnionymi stronami, a następnie wziąć w nich udział (Góralczyk, Sawicki, 2009: 384). Ze względu na odmienne znaczenie terminu ,spór” i „konflikt" należy wskazać, iż celem mediacji może być rozwiązanie sporu zanim on przekształci się w konflikt lub też zakończenie istniejącego już konfliktu.

Instytucja mediacji została ujęta w konwencji haskiej w sprawie pokojowego rozwiązywania sporów międzynarodowych z 1899 r. i w Karcie Narodów Zjednoczonych w art. 33, w którym to stwierdza się, że „strony w sporze, którego dalsze trwanie może zagrażać utrzymaniu międzynarodowego pokoju i bezpieczeństwa, będą przede wszystkim szukały rozwiązania w drodze rokowań, badań, pośrednictwa, pojednania, arbitrażu, rozstrzygnięcia sądowego, odwołania się do organizacji lub układów regionalnych, albo w drodze innych środków pokojowych według własnego wyboru" (Karta Narodów Zjednoczonych, 1945: art. 33). W teorii mediacji badacze koncentrują się na wielu elementarnych kwestiach dotyczących tego sposobu rozwiązywania sporów międzynarodowych. Przede wszystkim, istnieje szeroki zakres definiowania mediacji ze względu na różnorodność samej mediacji, podmiotów biorących w niej udział, jak i okoliczności jej towarzyszących. Według jednej z najprostszych definicji, mediacja jest „,formą regulowania sporu, która zakłada udział podmiotu zewnętrznego (outsider) lub tzw. trzeciej strony (third party), która nie jest bezpośrednio stroną sporu (Bercovitch, 1991: 3). Jacob Bercovitch proponował też bardziej zaawansowaną definicję, zgodnie z którą mediacja ,jest procesem regulowania sporu odnoszącym się i odrębnym od wzajemnych negocjacji stron sporu, w którym szukają one wsparcia lub chcą zaakceptować ofertę pomocy od podmiotu zewnętrznego (osoby fizycznej, organizacji, grupy

2 Mediatorem może zostać podmiot, który zostanie zaakceptowany przez zwaśnione strony. Podmiot ten może zostać wskazany przez strony sporu, bądź samodzielnie jest w stanie wyjść z inicjatywą mediacji wobec stron. Mediatorem może być państwo, organizacja międzynarodowa czy osoby fizyczne. 
państw, bądź państwa) w celu zmiany ich percepcji, bądź zachowania, czyniąc to bez odwoływania się do fizycznej przemocy lub mocy prawa (ibidem: 343).

Dużo miejsca w teorii mediacji poświęca się zarówno stronom zwaśnionym, jak i samemu mediatorowi. W przypadku stron rozważania naukowe są skoncentrowane na sześciu cechach: 1) ich identyfikacji; 2) ich zwartości; 3) ich typów ustroju; 4) ich motywacji, aby przyjąc mediację; 5) ich wcześniejszych i obecnych relacji; 6) rozłożenia siły między nimi (Kleiboer, 1996: 364-368). Z kolei przy charakterystyce mediatora wskazuje się na trzy jego kluczowe atrybuty, podkreślając bezstronność, zdolność oddziaływania oraz status. Bezstronność budzi wiele kontrowersji, bowiem w praktyce mediator nie musi wcale być „obiektywnie” bezstronny co byłoby jednoznaczne z terminem „,neutralny”, może on być związany z jedną ze stron sporu. Ważne jednak, aby został zaakceptowany przez strony sporu, które będą uznawały, iż ów mediator posiada odpowiedni potencjał i dysponuje zdolnościami, które pomogą w zażegnaniu konfliktu (ibidem: 369-370).

Ważne miejsce w teorii zajmuje strategia mediacji. Istnieje wiele różnych klasyfikacji strategii którą formułuje mediator biorąc pod uwagę własny potencjał, status i zdolność oddziaływania, status stron i okoliczności towarzyszące sporowi. Do najczęściej przywoływanych w literaturze typologii strategii mediacji zalicza się klasyfikację Kennetha Kressela oraz Saadi Touval i Williama I. Zartmana. Kressel w swojej typologii wyróżnił trzy podejścia: refleksyjne (reflective), niebezpośrednie (nondirective) i pośrednie (directive). Podejście refleksyjne jest najbardziej pasywną kategorią, w ramach której wszelkie działania mediatora mają na celu zapoznanie się ze specyfiką sporu i stworzenie bazy pod następne akcje. Podejście niebezpośrednie ma nieco bardziej aktywny charakter i zakłada minimalny udział mediatora w wypracowaniu przez strony obopólnego rozwiązania. Zaś podejście bezpośrednie określa bardzo aktywne działania mediatora formułuje rozwiązania sporu stosuje manipulację i wywiera presję na strony tak, aby doprowadzić do jego zakończenia (Kleiboer, 1996: 374-375; Bercovitch, Wells, 1993: 6).

S. Touval i W. I. Zartman zastosowali podział na strategię komunikacji (komunikacji i ułatwiania), formułowania i manipulacji. Strategia komunikacji zawiera m.in. takie elementy jak: ułatwianie wzajemnego kontaktu stron sporu, wypracowanie zaufania u stron skonfliktowanych, zdefiniowanie wszelkich kwestii i interesów czy przygotowywanie zarysu porozumienia. Strategia formułowania zawiera m.in. wybór miejsca i kontrolę przebiegu spotkań, opracowanie planu działania, sugerowanie rozwiązań, redukowanie napięcia pomiędzy stronami sporu. Zaś na strategię manipulacji składają się m.in. następujące elementy: zmian oczekiwań stron sporu, uświadamianie stronom kosztów braku porozumienia, nagradzanie stron za poczynione ustępstwa (Bercovitch, Wells, 1993: 5-6).

Kolejną kwestią nurtującą badaczy stanowi ostateczny efekt mediacji - kiedy zakończy się ona sukcesem, a kiedy porażką i co o tym decyduje? Proces mediacji składa się z czterech podstawowych elementów: stron konfliktu, mediatora, procesu mediacji i kontekstu w jakim mediacja jest prowadzona. Analiza specyfiki poszczególnych „części składowych” może dać odpowiedź w sprawie końcowego efektu mediacji (Bercovitch, 2009: 343).

Marieke Kleiboer wskazała też na trzy cechy sporu/konfliktu, które wpływają na ostateczny wynik mediacji, koncentrując się bardziej na samym problemie niż na stro- 
nach i na samym mediatorze. Są to: 1) dojrzałość sporu/konfliktu; 2) poziom intensywności sporu/konfliktu; 3) przedmiot sporu/konfliktu. Tutaj warto wskazać, że część autorów uważa iż mediacja jest najbardziej owocna kiedy fiasko osiagnięcia porozumienia oznacza wejście w sytuację krytyczną. Obawa przed tym stanem rzeczy znacznie motywuje obydwie strony do złagodzenia stanowisk i ponownego przeanalizowania swoich oczekiwań. Inni badacze uznają, że mediacja powinna być zainicjowana we wczesnym etapie, zanim strony wejdą na drogę przemocy co pociągnie za sobą straty (Kleiboer, 1996).

\section{ROLA I MIEJSCE KATARU NA BLISKIM WSCHODZIE}

Katar jest niewielkim państwem położonym w subregionie Zatoki Perskiej (11 437 tys. km²), zamieszkiwanym przez ok. 1 mln 900 tys. osób, w tym jednak prawdziwych Katarczyków jest ok. 15\%. Struktura etniczna jest dość zróżnicowana Arabów jest ok. 40\% (w tym katarscy i nie-katarscy Arabowie), 18\% Hindusów, 18\% Pakistańczyków, 10\% Irańczyków i 14\% pozostałych. Gospodarka Kataru znajduje się w fazie wysokiego wzrostu - w 2011 18,7\% PKB. PKB per capita mierzony parytetem siły nabywczej wynosi aż 102 tys. USD, co plasuje Katar na drugim miejscu na świecie po księstwie Lichtenstein. Złoża gazu ziemnego - ok. $26 \mathrm{bln}^{3}$, trzecie co do wielkości kolejno po Rosji i Iranie. Złoża ropy naftowej są szacowane na 15 mld baryłek. Gaz i ropa naftowa i jej pochodne stanowią ok. $80 \%$ katarskiego eksportu, chociaż należy pamiętać, że od 2008 r. wdrażany jest program Qatar Vison 2030, celem którego jest doprowadzenie do dywersyfikacji gospodarki katarskiej i jej uniezależnienie od sektora gazowo-naftowego (Ministerstwo Gospodarki, http://www.mg.gov.pl/node/13127).

Katar jest emiratem - głową państwa jest emir Tamim ibn Hamad as-Sani (do dnia swojej abdykacji 25 czerwca 2013 r. głową państwa był jego ojciec Hamad ibn Chalifa as-Sani). Emir mianuje premiera i radę ministrów. Legislatywę zgodnie z konstytucją z 2003 r. ma stanowić jednoizbowy parlament składający się z 45 przedstawicieli w tym $1 / 3$ ma być mianowana przez emira. Termin wyborów jest sukcesywnie przesuwany, miały one odbyć się już w 2006 r. Obecnie instytucja ta składa się wyłącznie z 35 osób mianowanych przez emira (Madeyska, 2008: 184-185).

Niewielkie państwo jak Katar musiało w przeszłości odnaleźć się w tyglu rywalizacji i zależności w subregionie Zatoki Perskiej. Szczególnie istotne miejsce w polityce Kataru zajmowały historycznie napięte relacje z Arabią Saudyjską, gdzie jeszcze przed II wojną światową saudyjski monarcha Abdelaziz as-Saud wskazywał, iż mieszkańcy Półwyspu Katarskiego są jego poddanymi i wchodzą w skład dira, czyli terytorium do którego rości sobie prawa plemienne (Wright, 2009: 73). Napięcia katarsko-saudyjskie były na tyle silne, że do uzyskania niepodległości przez Katar w 1971 r. władca Abd Allah ibn Jassim as-Sani prosił Wielką Brytanię o większe gwarancje dla swojego bezpieczeństwa realnie obawiając się zagrożenia ze strony Arabii Saudyjskiej (ibidem: 73). Kiedy Katar stał się niepodległym państwem stosunki z Arabią Saudyjską nie uległy znacznej poprawie. Dowodem na to były m.in. wciąż występujące dylematy związane z poddaństwem wobec właściwego władcy, w tym sprawa z 2005 r. dotycząca 5 tys. członków plemienia Murra, którzy w przeszłości zamieszkiwali pogranicze Kataru 
i Arabii Saudyjskiej i z tego tytułu posiadali oni podwójne obywatelstwo. Zostali oni pozbawieni katarskiego obywatelstwa, opieki medycznej oraz gwarancji bezpieczeństwa i zmuszeni tym samym do emigracji do Arabii Saudyjskiej. Władze Kataru nie podały oficjalnej przyczyny powodującej ten krok, ale zakładano, że była to zemsta za próbę odzyskania władzy na rzecz ojca emira zdetronizowanego w 1995 r. - Chalifę as-Saniego, który był bardziej konserwatywny od swojego syna i uzależniony od polityki Arabii Saudyjskiej (Madeyska, 2008: 185). W zasadzie w pierwszych latach XXI wieku relacje saudyjsko-katarskie były bardzo napięte. Efektem tego był silny kryzys w dwustronnych stosunkach dyplomatycznych. Oskarżano się o wrogą kampanię medialną i o finansowe wspieranie opozycji. Relacje te zostały znormalizowane po szczycie w Dżiddzie w 2007 r. m.in. w wyniku działań ze strony dyplomacji kuwejckiej. Udało się w wielu sprawach zawrzeć kompromis, o czym świadczyła zgoda Arabii Saudyjskiej na otwarcie w swoim kraju biura stacji al-Dżazira. Rozwiązano też sprawę utraty obywatelstwa członków plemienia al-Murra, którzy otrzymali możliwość jego odzyskania. Swój pozytywny wymiar miała także wizyta króla Arabii Saudyjskiej Abdallaha w Doha w grudniu 2007 r. (Wright, 2009: 85-86). Ponadto od końca XX wieku rozpoczął się proces regulowania kwestii wzajemnej granicy. W 1999 r. obie strony wyraziły zgodę na demarkację wzajemnej granicy, tam gdzie nie była ona jeszcze przeprowadzona. Natomiast w 2008 r. ostatecznie uzgodniono przebieg wspólnej granicy morskiej.

Dość skomplikowane były też relacje Kataru z Bahrajnem. Historia wzajemnych animozji sięga jeszcze czasów kiedy Katarem rządzili władcy z Bahrajnu. Szczególnie jednak „kość niezgody” stanowiły wyspy Hawar należące do Bahrajnu, ale położone nieopodal wybrzeża Kataru, w stosunku do których katarski emirat rościł sobie pretensje. Spór trafił w końcu do Międzynarodowego Trybunału Sprawiedliwości (MTS), a oba państwa zawiesiły stosunki dyplomatyczne. Sprawa przed MTS ciągnęła się 10 lat, a w międzyczasie strony rozszerzały zakres swoich roszczeń. Dopiero w $2001 \mathrm{r}$. sąd ostatecznie rozwiązał tę sprawę i podjął decyzję, że wyspy Hawar pozostały pod administracją Bahrajnu (Wiegand, 2012: 79-96; Maritime Delimitation, 2001).

Katar, w porównaniu do innych państw arabskich Zatoki Perskiej, utrzymuje pozytywne relacje $z$ Iranem, pomimo tego, że tuż po rewolucji islamskiej, obawiano się ferworu szyickiego m.in. wśród irańskiej mniejszości w Katarze. Podstawą jest wspólna eksploatacja tzw. złóż północnych gazu ziemnego. Towarzyszy temu szereg spotkań oficjalnych katarsko-irańskich. W 2007 r. władze Kataru zaprosiły nawet Iran po raz pierwszy w historii na posiedzenie Rady Współpracy Zatoki (ang. Gulf Cooperation Council) (Roberts, 2009: 100).

Na uwagę zasługują budowane już od dawna pozytywne relacje Kataru ze Stanami Zjednoczonymi, które są podmiotem gwarantującym bezpieczeństwo Kataru. W 1992 r. Katar zawarł z USA dwustronne porozumienia o współpracy w zakresie obronności. $\mathrm{Na}$ terytorium Kataru znajduje się baza lotnicza al-Udajd z Centrum Dowodzenia Sił Powietrznych USA.

W kontekście wysokiej konfliktogenności w regionie Bliskiego Wschodu i mozaiki antagonizmów szczególnie na tle konfliktu izraelsko-arabskiego należy wskazać, iż od lat 90-tych do początku XXI wieku Katar rozwijał relacje z Izraelem. W 1994 r. nawiązano kontakty w sprawie sprzedaży gazu ziemnego, w 1996 r. premier Szymon 
Peres złożył oficjalną wizytę w Katarze. W 1997 r. relacje zaczęły się pogarszać i Katar zamroził stosunki z Izraelem, ale nie zamknął biura handlowego w Doha, które było otwarte do wybuchu II intifady (Madeyska, 2008: 184).

Jak można zauważyć głównym celem w polityce zagranicznej Kataru jest utrzymywanie pozytywnych relacji z państwami, które często są ze sobą zantagonizowane lub nie uznają się na arenie międzynarodowej np. z Iranem i Izraelem. Jednocześnie zasadniczym celem w polityce zagranicznej Kataru, który udało się zrealizować, zwłaszcza po zamachu stanu z 1995 r. i przejęcia rządów przez obecnego władcę, było wyjście spod „parasola” Arabii Saudyjskiej i prowadzenie własnej niezależnej polityki zagranicznej.

\section{MEDIACJA KATARU NA BLISKIM WSCHODZIE I W AFRYCE}

W publikacjach poświęconych mediacji Kataru najczęściej opisywane są trzy przykłady katarskiego pośrednictwa: w konflikcie pomiędzy rządem sudańskim a niearabskimi mieszkańcami prowincji Darfur; w sporze politycznym w Libanie między rządem a opozycją oraz $\mathrm{w}$ konflikcie pomiędzy rządem jemeńskim a rebeliantami z prowincji Sa'ada (Kamrava, 2011: 545-552; Roberts, 2009: 5-8). Niewątpliwe są one najbardziej modelowe dla katarskich działań w tym zakresie, toteż z tego powodu rzadko szerzej omawia się inne próby mediacji. W zasadzie szerokie zestawienie mediacji (także wstępnych prób pojednawstwa) ze strony Kataru zaprezentował Allen J. Fromherz, który nie dokonał jednak ich szczegółowego przedstawienia. Wskazał on na 9 mediacji, które prowadził emirat od 2003 r., uzasadniając, że wszystkich nie sposób jest podać ze względu na to, iż w wielu przypadkach działania dyplomatyczne Kataru miały charakter nieoficjalny i informacje na ten temat nie przedostały się do informacji publicznej. Są to mediacje w sporach między:

- Libią a USA i Wielką Brytanią w 2003 r.;

- Czadem a Sudanem (mediacja katarska i libijska) w 2008 r.;

- Irakiem, rządzonym przez Saddama Husajna a USA (nieudana próba mediacji);

- Fatahem a Hamasem w 2006 r.;

- rządem libańskim a opozycją w 2008 r.;

- Iranem a Zjednoczonymi Emiratami Arabskimi;

- rządem a rebeliantami z klanu al-Husi w konflikcie jemeńskim;

- rządem sudańskim a reprezentacją ludności Darfuru w konflikcie w Sudanie;

- Algierią i Marokiem i Frontem Polisario (Fromherz, 2012: 89-90).

O ile usprawiedliwiony jest niekompletny charakter zestawienia to na krytyczną uwagę zasługuje nieuwzględnienie mediacji katarskiej między Erytreą a Dżibuti, która z sukcesem zakończyła długotrwały spór graniczny. Aktualnie warty uwagi jest także fakt zaangażowania się Kataru w prawdopodobne rozmowy między prezydentem Afganistanu Hamidem Karzajem a Talibami. Z tego powodu rząd katarski wyraził zgodę na otwarcie w Doha biura łącznikowego Talibów (Karzai in Doha, 2013).

Biorąc pod uwagę powyższe rozważania przedstawione zostaną trzy wspomniane i najbardziej reprezentatywne przykłady mediacji katarskiej oraz jeden z przykładów, które z reguły w literaturze przedmiotu nie podlegają szerszym opisom. 


\section{Mediacja w konflikcie libańskim}

Po zakończeniu wojny Hezbollahu z Izraelem („,wojna lipcowa”) w 2006 r. sytuacja polityczna w Libanie dalej pozostawała napięta. Przeciwko polityce rządu ówczesnego premiera Fuada Siniory zaczęły organizować się protesty, do których nawoływał opozycyjny blok Ruchu 8 Marca. Główne ogniwa opozycji stanowił wówczas szyicki Hezbollah z AMAL-em i Wolny Ruch Patriotyczny (at-Tajjar al-Watani al-Hurr - WRP), na czele którego stał Michel Aun. Wcześniej, 6 lutego 2006 r. WRP podpisał z Hezbollahem porozumienie (ang. Memorandum of Understanding) wymierzone w rządy Siniory. Celem tego układu było przede wszystkim utworzenie rządu jedności narodowej (Turek, 2008, 89-98). W drugiej połowie $2006 \mathrm{r}$. zaczęła się formować pod egidą ONZ idea powołania specjalnego trybunału na rzecz zbadania sprawy zabójstwa byłego premiera Rafika Haririego. Nieoficjalne informacje, jakie docierały do wiadomości opinii publicznej wskazywały na bezpośredni związek z zabójstwem wywiadu syryjskiego i członków Hezbollahu. Wywołało to ostrą reakcję w kierownictwie Hezbollahu w tym samego sekretarza generalnego Hassana Nasrallaha, który pod koniec października ostrzegał przed ulicznymi demonstracjami, jeśli nie uda się uformować rządu jedności narodowej. W wyniku narastającego konfliktu w listopadzie do dymisji podało się pięciu ministrów ( 2 z Partii Boga, 2 z AMAL-u i jeden niezależny), a następnie dołączył do nich szósty minister, co nastąiło dwa dni przed zebraniem się rządu w sprawie omówienia projektu ONZ dotyczącego trybunału ds. zabójstwa R. Haririego. Koalicja szyicka - Hezbollahu i AMAL-u z Michelem Aunem powoływała się w tej sytuacji na art. 69 Konstytucji Libanu, zgodnie z którym rezygnacja 1/3 gabinetu automatycznie powinna prowadzić do upadku całego rządu (Konstytucja Libanu). Siniora nie przyjął dymisji, a prezydent Emil Lahud pomimo zapisu w konstytucji w dalszym ciagu uznawał premiera Siniorę za szefa rządu, co jedynie zaostrzało konflikt polityczny (Shields, 2008: 486).

Pozostali w rządzie ministrowie zaakceptowali ustanowienie trybunału (Specjalny Trybunał ds. Libanu). Pomimo tego prezydent Lahud uznał tę decyzję za bezwartościową, gdyż została ona podjęta przez rząd bez udziału szyickiej reprezentacji. Ponadto do wzrostu napięcia politycznego przyczyniło się w tym czasie zabójstwo ministra przemysłu Pierre'a Amina Dżumajjila - syna byłego prezydenta Libanu Amina Dżumajjilla. P. A. Dżumajjill aktywnie sprzeciwiał się polityce syryjskiej prowadzonej wobec Libanu (Pierre Amin Gemayel, 1972-2006). Jego pogrzeb przyciagnął setki tysięcy uczestników i przerodził się w antysyryjską manifestację (Thousands, 2006). Z kolei lider Hezbollahu Nasrallah nawoływał do pokojowych demonstracji antyrządowych, które coraz częściej zaczęły odbywać się w Bejrucie i innych większych miastach Libanu. W wielu przypadkach dochodziło do starć przeciwników rządu ze zwolennikami i ze służbami porządkowymi. Tak było m.in. 3 grudnia 2006 r., kiedy w starciach zginął młody zwolennik szyickiego AMAL-u Ahmad Ali Mahmud (Blanford, 2006).

W 2007 r. kryzys polityczny pogłębiał się. Uspokojeniu jego nie sprzyjały walki, które wybuchły w maju w palestyńskim obozie Nahr al-Berid, którym kierowała radykalna sunnicka organizacja Fatah al-Islam, powiązana z al-Kaidą. Wówczas do obozu została skierowana armia libańska, która opanowała sytuację dopiero na początku 
września. Operacją dowodził m.in. Michel Sulejman, który po tych wydarzeniach stał się kandydatem na prezydenta Libanu. Zanim jednak został on prezydentem, w obliczu kryzysu politycznego koalicja 8 marca i koalicja 14 marca nie mogły osiagnąć porozumienia co do wyboru prezydenta. Pomimo, że kadencja E. Lahouda dobiegła końca w listopadzie 2007 r. Sulejman został wybrany przez parlament na prezydenta dopiero pod koniec maja 2008 r., już w wyniku zawartego wcześniej porozumienia politycznego pomiędzy zwaśnionymi obozami.

Z miesiąca na miesiąc Liban zaczął pogrążać się w instytucjonalnej zapaści, której apogeum była zbrojna eskalacja konfliktu w maju 2008 r., po tym jak rząd zamknął niezależną sieć telekomunikacyjną Hezbollahu i podjął kilka ważnych decyzji na rzecz wzmocnienia bezpieczeństwa (Knio, 2008: 449). Przede wszystkim usunięto ze stanowiska szefa bezpieczeństwa lotniska gen. Wafika Szukejra, zarzucając mu sympatię wobec Hezbollahu. Rząd uznał, że te działania zapobiegły najprawdopodobniej zamachowi, który przygotowywał Hezbollah na obszarze lotniska. Partia Boga z kolei uznała to za „deklarację wojny”, po czym następnego dnia uzbrojeni członkowie Hezbollahu wyszli na ulice Bejrutu (ibidem).

Starcia uliczne rozprzestrzeniły się poza Bejrut i miały miejsce w Trypoli, a także w górach Libanu. Trwały od 8 do 14 maja. Dopiero realna groźba interwencji armii libańskiej doprowadziła do zaprzestania walk. W starciach zwolenników i przeciwników rządu zginęło ponad 60 osób (Lebanon. Current Conflicts, 2013).

Zaangażowanie Kataru w rozwiązanie sporu politycznego w Libanie nie było przypadkowe. Po pierwsze i co jest najważniejsze, strony skonfliktowane muszą wyrazić zgodę na proponowanego mediatora. Pozycja Kataru w tej kwestii okazała się bardzo mocna. Państwo to nie było dotychczas zaangażowane w politykę wewnętrzną Libanu, nie wspierało, ani nie opowiadało się bezpośrednio po żadnej ze stron silnie spolaryzowanej sceny politycznej tego państwa. Dotyczyło to zarówno wydarzeń z lat 2006-2008, jak i wcześniejszych wszelkich konfliktów w Libanie. Katar zatem przystępował do mediacji z „czystą kartą” jako faktycznie bezstronny podmiot. Takiej roli nie mogłaby spełniać ani Syria, Arabia Saudyjska czy Iran obciążone historycznym, a także w przypadku Syrii militarnym zaangażowaniem w sprawy Libanu.

17 maja 2008 r. 14 przedstawicieli zwaśnionych stron politycznych (w tym m.in. lider Druzów Walid Dżunbulatt, lider Sit Libańskich - Samir Dżadża, lider Wolnego Ruchu Patriotycznego - Michel Aun, przewodniczący parlamentu - Nebih Berri, reprezentujący Hezbollah w zastępstwie szajcha Hassana Nasrallaha-Mohammed Ra'ad, premier Fuad Siniora) spotkało się na zaproszenie emira Kataru Hamada ibn Chalify as-Saniego i premiera Hamada ibn Jassima as-Saniego w stolicy Kataru - Doha.

Do rozwiązania pozostawały dwie zasadnicze i różniące strony sprawy: wypracowanie zgody co do osoby przyszłego prezydenta oraz zmiana prawa wyborczego przed następnymi wyborami parlamentarnymi. Od razu ujawniła się główna platforma rozmów na linii Hezbollah-premier F. Siniora z koalicją 14 marca. Na wstępie strony poszły na ustępstwa, aby łatwiej można było prowadzić rozmowy i rząd wycofał się z oskarżeń, że to Hezbollah rozpoczął kryzys, z kolei Partia Boga wycofała swoje siły z obszarów Bejrutu, które były przez nie okupowane (Kamrava, 2011: 547). Stanowiło to preludium do dalszych uzgodnień. 
Po pięciu dniach intensywnych rozmów przy bardzo aktywnej postawie mediatora katarskiego udało się libańskim stronom sporu zawrzeć porozumienie, które jest nazywane Porozumieniem z Doha. Układ ten składa się z pięciu postanowień. W pierwszym ustalono, że nastapi specjalne posiedzenie parlamentu, aby dokonać wyboru zaakceptowanego przez wszystkie strony Michela Sulejmana na prezydenta Republiki Libańskiej. W drugim zapowiedziano utworzenie rządu jedności narodowej składającego się z 30 ministrów, w tym 16 reprezentowanych przez koalicję rządząca, 11 przez opozycję, a 3 mianowanych bezpośrednio przez prezydenta. Trzecie postanowienie dotyczyło zmian w prawie wyborczym i podzielenia Bejrutu na trzy dystrykty wyborcze. W czwartym postanowieniu przyjęto, że strony będą powstrzymywać się od użycia broni i przemocy w celu uzyskania korzyści politycznych. Ponadto będą działać na rzecz inicjacji dialogu promującego zwierzchnictwo państwa libańskiego nad całym jego terytorium oraz na rzecz bezpieczeństwa państwa i obywateli. W ostatnim postanowieniu ustalono, że porozumienie zostanie zarejestrowane w Sekretariacie Generalnym Ligi Państw Arabskich zaraz po tym jak zostanie zawarte (Doha Agreement, 2008).

Porozumienie z Doha kończyło 18 miesięczny kryzys polityczny w Libanie, który nieuchronnie zmierzał do eskalacji konfliktu, a nawet do wybuchu wojny domowej.

\section{Mediacja w konflikcie w Sudanie}

Konflikt w Darfurze - zachodniej prowincji Sudanu wybuchł w 2003 r., kiedy zamieszkująca tam czarnoskóra (niearabska) ludność zażądała praw, jakie przysługiwały arabskiej ludności Sudanu. Tłem tego było jawne faworyzowanie arabskich nomadów względem niearabskich rolników. Szybko doszło do zbrojnych starć pomiędzy rebeliantami z Darfuru a arabskimi siłami „dżandżawidami”, które zostały uformowane z przedstawicieli prawie 30 plemion arabskich (Salih, 2008: 9). W konflikcie tym rebeliantów reprezentowały dwie główne siły polityczno-militarne reprezentujące czarnoskórych mieszkańców Darfuru: Ruch Sprawiedliwości i Równości (Harakat al-Adal wa al-Musawa - RSR) oraz Ludowa Armia Wyzwolenia Sudanu (Harakat asz-Szabijja li-Tahrir as-Sudan - LAWS).

Konflikt ten doprowadził to poważnej katastrofy humanitarnej. Według szacunków ONZ śmierć w działaniach wojennych poniosło ok. 300 tys. ludzi, a 2,7 mln uciekło do sąsiedniego Czadu, gdzie znaleźli się w obozach dla uchodźców (Konflikt, 2013). W efekcie tego w 2008 r. prokurator Międzynarodowego Trybunału Karnego Luis Moreno Ocampo wszczął dochodzenie przeciwko urzędującej głowie państwa prezydentowi Sudanu Omarowi al-Baszirowi, stawiając zarzuty o ludobójstwo w Darfurze.

Próby rozwiązania konfliktu były podejmowane już w pierwszych miesiącach po jego wybuchu. Od 2004 r. toczyły się rokowania pomiędzy skonfliktowanymi stronami. W kwietniu tego roku udało się podpisać humanitarne porozumienie rozejmowe w stolicy Czadu N'djamenie. W 2006 r. zawarto po dwuletnich negocjacjach pod auspicjami Unii Afrykańskiej porozumienie pokojowe - Darfur Peace Agreement (DPA). Chociaż stronami był rząd sudański i tylko jedna z frakcji LAWS, uznano to za pierw- 
szy krok ku stabilizacji i rozwiązaniu konfliktu ${ }^{3}$. W rzeczywistości DPA miało wiele słabości, m.in. brak wprowadzenia gwarancji co do rozbrojenia „dżandżawidów” i bezpiecznego powrotu uchodźców. Nie definiowano jasno kim są „dżandżawidzi”, co przekładało się ściśle na aspekt ich rozbrojenia (Darfur's Fragile, 2006: 4-5).

Po zawarciu DPA sytuacja w Darfurze nie uległa normalizacji. W dalszym ciągu były prowadzone działania zbrojne i to pomimo ustanowienia w $2007 \mathrm{r}$. wspólnie $\mathrm{z}$ inspiracji ONZ i Unii Afrykańskiej misji pokojowej w Darfurze - UNAMID ${ }^{4}$. W lutym 2010 r. został zawarty rozejm w Chartumie między rządem a RSS. W następstwie tego zakładano wymianę jeńców, partycypację RSR na wszystkich szczeblach rządowych i rekompensatę dla uchodźców. Zawarcie tego porozumienia stanowiło efekt wysiłków dyplomatycznych rządu Kataru, Czadu, Erytrei i specjalnych wysłanników Unii Afrykańskiej i ONZ (Dagne, 2011). Rozejm szybko został zerwany, po tym jak strona rządowa rozpoczęła militarną ofensywę w Górach Marra (Rice, 2010).

Dopiero ponowna i intensywna aktywność dyplomatyczna Kataru przyczyniła się do zawarcia 14 lipca 2011 r. w Doha porozumienia pokojowego pomiędzy rządem Sudanu a zrzeszającym wiele mniejszych ugrupowań rebelianckich Ruchem Wyzwolenia i Sprawiedliwości (Harakat at-Tahrir wa al-Adal-RWS). Układ ten kończył formalnie wojnę w Darfurze. Na jego mocy udało się powołać Fundusz na rzecz Odbudowy Darfuru przy niebagatelnym wsparciu emira Kataru, który wcześniej ustanowił Bank Rozwoju Darfuru i zorganizował międzynarodową konferencję donatorów w sprawie tego sudańskiego regionu (Baatout, 2013). Ponadto zapowiedziano włączenie przedstawicieli politycznych Darfuru do rządu sudańskiego, w tym pojawiła się możliwość, aby jednym z wice-prezydentów była osoba z Darfuru (część 3-8). Ustanowiono także Regionalny Rząd Darfuru z siedzibą w al-Fasir, który zastąpił powołany na mocy układu z 2006 r. - Tymczasowy Regionalny Rzad Darfuru (Doha Document for Peace, 2011).

Rząd Kataru nie poprzestał na mediacji w konflikcie w Darfurze i jej zakończeniu kiedy podpisano porozumienie z $2011 \mathrm{r}$. Od tamtego czasu jednym z celów w polityce zagranicznej Kataru wobec Darfuru jest monitorowanie sytuacji na rzecz utrzymania stabilności i dotrzymywania warunków zawartego układu pokojowego. $Z$ tego powodu m.in. w dniach 7-8 kwietnia 2013 r. po raz kolejny zorganizowano międzynarodową konferencję donatorów na rzecz odbudowy i rozwoju Darfuru. Konferencja odbyła się z udziałem przedstawicieli rządu Sudanu, a jednym z jej podstawowych celów było przyjęcie strategii odbudowy i rozwoju Darfuru na lata 2013-2019 (International Donor Conference, 2013).

\section{Mediacja w konflikcie w Jemenie}

Konflikt jemeński określany mianem rebelii al-Husi ma swoją genezę jeszcze w 1962 r., kiedy na terytorium obecnego Jemenu funkcjonowały dwa podmioty - Jemen Północny ze stolicą w Sa'anie i brytyjski protektorat Adenu, który w 1967 r., po uzyskaniu niepodległości i wycofaniu się stamtąd Brytyjczyków stał się w 1970 r. Je-

3 Układ podpisała frakcja Minniego Arku Minawiego.

4 UNAMID - Hybrydowa Operacja Unii Afrykańskiej i Narodów Zjednoczonych w Darfurze. 
meńską Republiką Ludowo-Demokratyczną. Wtedy w 1962 r. w Jemenie Północnym dokonano zamachu stanu, obalając imamat i w jego miejsce powołana została Jemeńska Republika Arabska, która ideowo utożsamiała się z Egiptem rządzonym przez Gamala Abd an-Nasira (Madeyska, 2008: 105-109).

Wydarzenia $\mathrm{z}$ lat 60 . XX wieku miały istotny związek $\mathrm{z}$ tym co wydarzyło się w XXI wieku w prowincji Sa'ada położonej na obszarze dawnego Jemenu Północnego. W 2004 r. w tejże prowincji rozpoczęła się antyrządowa rebelia, w której dominującą rolę odgrywał zajdycki (szyicki) klan rodowy al-Husi. Rebelia ta do 2010 r. miała aż sześć swoich odsłon. Szyiccy rebelianci domagali się restytucji imamatu, obalonego w 1962 r. i tym samym końca republiki pod rządami Alego Abdullaha Saliha. Walki toczyły się przede wszystkim w górzystej i trudno dostępnej prowincji Sa'ada, w której siłom rządowym niełatwo było pokonać rebeliantów. Konflikt szybko został umiędzynarodowiony i zaangażowanymi stronami stały się przede wszystkim USA, wspierające Saliha; Arabia Saudyjska, która w ostatniej fazie konfliktu wysłała do Jemenu swoje siły zbrojne, a także Iran, który wspierał finansowo i militarnie rebeliantów (Ożarowski, 2010: 56-68).

Początki zaangażowania Kataru w rozwiązanie sporu w Jemenie sięgają 2007 r. Wówczas oficjalną wizytę w stolicy Jemenu złożył emir Hamid Ibn Chalifa as-Sani, który zaproponował podjęcie się mediacji w konflikcie jemeńskim. Przy okazji tej wizyty emir zapowiedział pomoc $\mathrm{w}$ sfinansowaniu odbudowy zniszczonej prowincji Sa'ada z funduszy państwa katarskiego (Kamrava, 2011: 549). Towarzyszyła temu czwarta odsłona rebelii, która formalnie zakończyła się 16 czerwca 2007 r. w stolicy Kataru zawarciem rozejmu. Pomimo, że rozejm był wielokrotnie naruszany przedstawiciele rebeliantów i strony rządowej ponownie spotkali się w Katarze i podpisali porozumienie regulujące szczegółowo warunki wprowadzenia w życie wcześniej zawartego zawieszenia broni (Peterson, 2006; Hamidi, 2009: 169). Jednak zawarcie porozumienia nie zakończyło walk. Wkrótce rozpoczęły się kolejne odsłony rebelii i tym samym mediacyjne zabiegi Kataru w efekcie nie przyniosły określonego rezultatu. Dopiero w lutym $2010 \mathrm{r}$. rebelianci i strona rządowa zawarła sześciopunktowe porozumienie rozejmowe (Ożarowski, 2010: 68; Salmoni, Loidolt, Wells, 2010: 313).

Po ponownym wybuchu walk rebeliantów al-Husi z innymi plemionami, które opowiadały się za rządem Alego Saliha, emir Kataru po raz drugi wystąpił z inicjatywą mediacji pomiędzy skonfliktowanymi stronami. W efekcie w sierpniu $2010 \mathrm{r}$. w stolicy Kataru podpisane zostało kolejne porozumienie na rzecz wzmocnienia kruchego rozejmu. Ustalono m.in., że rebelianci przekażą skradzioną broń sił rządowych katarskiemu mediatorowi, podczas gdy strona rządowa zwolni z więzień przetrzymywanych rebeliantów; dojdzie do rozminowania terenów objętych konfliktem i pozwolenia na swobodny powrót osób, które w wyniku konfliktu zostały zmuszone do ucieczki ze swojego miejsca zamieszkania (Ghobari, 2010).

\section{Mediacja w sporze Erytrei z Dżibuti}

Geneza sporu terytorialnego pomiędzy Erytreą i Dżibuti sięga jeszcze lat 90. ubiegłego wieku. W 1996 r. omal niedoszło do wybuchu wojny pomiędzy tymi pań- 
stwami, kiedy to rząd Dżibuti oświadczył, że wojsko Erytrei ostrzelało przygraniczną wioskę Ras Doumeirah, która znajdowała się w obszarze spornym. Po tym incydencie siły Erytrei wycofały się, a rząd tego państwa nie podtrzymywał swoich roszczeń (Mesfin, 2008). Mimo wszystko stosunki Erytrei z Dżibuti uległy znacznemu pogorszeniu. Powodem tego było wojna Erytrei z Etiopią i pojawiające się w tym czasie oskarżenia ze strony Erytrei kierowane wobec rządu Dżibuti o sprzyjanie stronie etiopskiej, w tym umożliwianie transportu broni dla sił etiopskich przez port w Dżibuti. Dopiero w $2000 \mathrm{r}$. przy pomocy mediacji libijskiej udało się znormalizować relacje pomiędzy obydwoma państwami. Przywódcy obydwu państw nawzajem odbyli wizyty państwowe, a w 2004 r. podpisano porozumienia na rzecz współpracy w dziedzinie politycznej, gospodarczej i społecznej (ibidem).

Sytuacja ponownie uległa pogorszeniu w lipcu 2008 r., a przedmiotem sporu ponownie stała się wioska Ras Dumeira, wzgórze Gabla i wyspa Doumeira, która jako obszar niezamieszkały stanowiła jedynie przystań dla okolicznych rybaków. Wówczas doszło do starć sił Erytrei i Dżibuti (Qatar to mediate, 2010). W sporze tym strony miały spore trudności z ustaleniem właściwego przebiegu granicy. Państwa kolonialne Włochy, które sprawowały rządy na obszarze dzisiejszej Erytrei i Francja, której kolonią było Dżibuti nie zdefiniowały jasno przebiegu granicy pomiędzy swoimi koloniami, ustalając jedynie w protokole z 1900 r., że żadna strona nie będzie sprawować jurysdykcji nad wyspą Doumeira. W 1935 r. Francja i Włochy podpisały kolejne porozumienie dotyczące granicy pomiędzy tymi koloniami. W ramach tej umowy Francuzi zrzekli się praw do wyspy na rzecz Włochów. Porozumienie to jednak nie zostało ratyfikowane przez Francję, stąd protokół z 1900 roku nie stracił swojej mocy (Mesfin, 2008: 6).

Siły Erytrei wycofały się ze spornego terytorium dopiero na początku czerwca 2010 r., kiedy to obie strony konfliktu zgodziły się na mediację katarską i przekazały emirowi Kataru Hamidowi Ibn Chalifie as-Saniemu prawo do podjęcia działań na rzecz rozwiązania sporu. Zostało to zapisane w porozumieniu zawartym 8 czerwca $2010 \mathrm{r}$. między Erytreą i Dżibuti (Eritrea - Djibouti Agreement, 2010). Na tej podstawie w Dokumencie Wykonawczym Porozumienia zapowiedziano powołanie specjalnego komitetu pod przewodnictwem premiera rządu katarskiego wraz z jednym przedstawicielem każdej strony sporu w celu uregulowania przebiegu granicy. Strony sporu zostały zobligowane do dostarczenia katarskiemu mediatorowi pełnych list jeńców wojennych i przeprowadzenia śledztwa wyjaśniającego w sprawie osób zaginionych (Executive Document of the Agreement, 2010: art. 1, 3). Od momentu zawarcia porozumienia, na czas rozwiązania sporu na terytoria sporne wkroczyli żołnierze katarscy jako siły pokojowe w liczbie około 700 (Qatar to deploy, 2013). Mediacja Kataru miała pełne poparcie ONZ i Unii Afrykańskiej.

\section{MEDIACJA W STRATEGII POLITYKI ZAGRANICZNEJ KATARU}

Działania dyplomatyczne Kataru w formie mediacji należy uznać za kluczowy element strategii polityki zagranicznej Kataru. Lina Khatib w swoim opracowaniu o polityce zagranicznej tego państwa wskazała nawet, że mediacja jest „ulubioną metodą 
polityki zagranicznej Kataru" (ang. Qatar's preferred foreign policy method), ponieważ pozwala ona na niezajmowanie stanowiska w sprawach spornych, kreuje status podmiotu neutralnego i przyjaznego wobec każdego innego państwa (Khatib, 2013: 429). Przy tej okazji warto postawić pytanie - jakie są powody, dla których Katar zaangażował się w dyplomatyczne rozwiazywanie sporów międzynarodowych i uczynił $\mathrm{z}$ tego ważne narzędzie w swojej polityce zagranicznej? Przede wszystkim prowadzenie mediacji jest przedsięwzięciem korzystnym i nie pociaga za sobą ryzyka porażki. W praktyce mediator jest nagradzany kiedy osiaga sukces i nie jest obwiniany w przypadku fiaska (Dickinson, 2012). Katar mimo korzystnych uwarunkowań mediacji przed przystapieniem do tego procesu zachowuje dużą ostrożność. Teoretycznie wydawałoby się, że bierze on udział w wielu różnych sporach i konfliktach, jednak co należy tu wyraźnie wskazać, przed zaangażowaniem się w roli mediatora, emir i rząd katarski dokonują głębokiej analizy określonego sporu, przede wszystkim oceniając relatywne korzyści, które z ich udziału mogą wyniknąć. W ten sposób emirat minimalizuje ryzyko uwikłania się w sytuacje nacechowane dużym stopniem trudności w ewentualnym procesie rozwiązywania sporu (Kamrava, 2011: 544-545). Zatem „dobór” sporów i konfliktów, w których można podjąć się roli mediatora jest ze strony władz Kataru działaniem celowym, które wpisuje się w strategię państwa realizowaną od wielu lat. Strategia ta polega na budowaniu wiarygodnej marki państwa na arenie międzynarodowej, wzmacnianiu swojego bezpieczeństwa i stabilności oraz na tworzeniu własnej strefy wpływów. Mediacja stanowi metodę w osiaganiu tych celów i realizacji założonej strategii ${ }^{5}$.

Należy podkreślić, że zwieńczeniem mediacji katarskiej czy to w przypadku konfliktu w Sudanie, Jemenie, Libanie i omawianego w tekście sporu między Dżibuti i Erytreą było doprowadzenie stron do zawarcia porozumienia, które potem zostaje obwieszczone światowej opinii publicznej. Nie mają tu znaczenia, istotne już w dalszym procesie, długofalowe efekty mediacji, m.in. nadzór nad wprowadzaniem postanowień w życie, czy działania na rzecz stabilizacji na obszarze skonfliktowanym, które w wydaniu dyplomacji katarskiej nie wyglądały już najlepiej. Sam fakt doprowadzenia stron często toczących wieloletnie spory do porozumienia jest uważany za sukces i na tym buduje się pozycję i wizerunek państwa efektywnego w swoim działaniu, co z kolei umacnia jego pozycję na arenie międzynarodowej. Stanowi to element przygotowanej strategii, bowiem jak wskazuje Mehran Kamrava, Katar nie posiada odpowiednio rozbudowanego i doświadczonego personelu dyplomatycznego, który posiadałby zdolność do dłuższego monitorowania postępów w zakresie przyjętych ustaleń (ibidem: 556).

$Z$ tego powodu mediacja Kataru opiera się na działaniach indywidualnych dosłownie kilku osób, w tym emira Hamida ibn Chalify as-Saniego, następcy tronu szajcha Tamima ibn Hamida as-Saniego i premiera szajcha Hamida ibn Jassina as-Saniego (Khatib, 2013: 418). Szerokie kontakty i dobre relacje emira z przywódcami często wrogich wobec siebie państw, jak m.in. Iranu, Arabii Saudyjskiej, a nawet Izraela (Rabi, 2009: 443-459) ułatwiają w wielu przypadkach rolę mediatora. Na bazie sukcesów dyplomatycznych Katar zbudował sobie mocną pozycję w bardzo newralgicz-

5 Lina Khatib wskazuje utrzymanie własnego bezpieczeństwa i stabilności oraz rozszerzanie własnych wpływów jako motywacje mediacji. W mojej ocenie są to cele strategii a mediacja, jak wskazano w tekście, jest narzędziem realizacji tych celów. 
nym środowisku międzynarodowym Bliskiego Wschodu. Otoczony silniejszymi pod względem potencjału demograficznego i militarnego podmiotami udowodnił, że jego soft power jest o wiele bardziej efektywna niż odnoszenie się do hard power przez wiele państw tego regionu. Curtis Ryan wskazał nawet, że Katar stał się regionalną potęga, a wzrost jego znaczenia i pozycji międzynarodowej można uznać za najdziwniejszy fenomen współczesnego świata arabskiego (Ryan, 2012). W efekcie Katar poprzez udaną mediację ograniczył na różnych obszarach wpływy innych państw, które wcześniej tam dominowały. W Jemenie Arabia Saudyjska, jako strona konfliktu, musiała uznać obecność Kataru; w Libanie Katar pojawił się jako nowy gracz na silnie umiędzynarodowionej scenie politycznej tego kraju pokazując, że wszystkie państwa, które miały jakiekolwiek wpływy w Libanie w historii istnienia tego państwa stały się mniej niewiarygodne. Pojawienie się dyplomacji katarskiej w Sudanie osłabiło polityczną dominację Egiptu, który w XX w. traktował Sudan jako swoją historyczną strefę wpływów (Kamrava, 2011: 555).

Mediacja Kataru służy nie tylko jego umacnianiu politycznemu, ale stanowi także środek realizowania polityki gospodarczej. Podczas mediacji w wielu przypadkach Katar deklarował swoje zainteresowanie inwestycjami gospodarczymi w państwach objętych konfliktami. Tak było podczas mediacji w Libanie, Jemenie i Sudanie. Wielu autorów publikacji podkreśla istotną rolę oddziaływania czynnika ekonomicznego podczas mediacji prowadzonej przez emirat (ibidem: 544; Roberts, 2009: 10). Można zatem uznać, że olbrzymi jak na wielkość Kataru potencjał ekonomiczny i zdolność do wykorzystywania czynnika ekonomicznego w polityce międzynarodowej są jednymi z ważniejszych elementów procesu mediacji, które często nie są mocno eksponowane. Bez tego Katar nie byłby w stanie efektywnie wypełniać roli mediatora.

W przypadku Libanu, Katar już na początku XXI wieku był w istotnym stopniu obecny na rynku libańskim. Z czasem jednak inwestycje katarskie i wymiana handlowa pomiędzy tymi krajami zaczęła rosnąć. W $2003 \mathrm{r}$. bilans handlowy pomiędzy obydwoma państwami wynosił 14 mln USD (Saadi, 2003). Podczas mediacji Katar zobowiązał się, że po zawarciu porozumienia zainwestuje w Libanie $300 \mathrm{mln}$ USD. Poza tym Katar celowo także zwiększył w tym czasie swoje inwestycje w Syrii, aby pozyskać przychylność Syryjczyków przy mediacji w sporze libańskim (Barakat, 2012: 19). Według danych z 2012 r. Katar jest dziewiątym co do wielkości partnerem handlowym Libanu (wielkość obrotów to 503 mln euro), wyprzedzając m.in. Kuwejt, Arabię Saudyjską, Rosję, Japonię i Indie (Lebanon. EU bilateral, 2012).

Podczas mediacji dotyczącej konfliktu w Sudanie czynnik finansowy odegrał kluczową rolę. Najpierw Katar zobowiązał się do inwestycji rzędu 1 mld USD, aby potem podwyższyć je do 2 mld USD (Roberts, 2009: 20). W Jemenie przed zawarciem porozumienia pomiędzy rządem a rebeliantami Katar obiecał przyznanie środków wysokości od 300 do $500 \mathrm{mln}$ USD na rekonstrukcję prowincji Sa'ada (Barakat, 2012: 16).

W odniesieniu do części teoretycznej i bazując na zaprezentowanych przykładach mediacji z udziałem Kataru należy wskazać, iż władze emiratu katarskiego wykorzystały w pełni atrybuty mediatora: bezstronność i zdolność oddziaływania. Bezstronność 
wynikała z tego, iż władze Katar wcześniej nie angażowały się w spory i konflikty na Bliskim Wschodzie. Nie zajmowały także stanowiska w takim stopniu, aby zrazić sobie strony sporu. Zatem od samego początku jego wiarygodność jako bezstronnego mediatora była bardzo wysoka. Wszystko to poparte potencjałem gospodarczym i rozwiniętymi kanałami komunikacji pomiędzy emirem i premierem Kataru, a innymi przywódcami państw Bliskiego Wschodu umożliwiło Katarowi osiagnięcie statusu regionalnego peacebrokera.

Pozwala to na pozytywną ocenę perspektyw dyplomatycznej aktywności Kataru na Bliskim Wchodzie i w Afryce. Obecnie wiele zwaśnionych stron, które mają świadomość sukcesów Kataru, skłania się ku „opcji” katarskiego mediatora i być może w przyszłości skierują do niego propozycję podjęcia się rozwiązania sporu. Wśród nich można obecnie wskazać Talibów, którzy metodą drobnych koków próbują nawiązać bliższe relacje $\mathrm{z}$ emiratem.

\section{Bibliografia}

Barakat S. (2012), The Qatari Spring: Qatar's emerging role in peacemaking, „Kuwait Programme on Development, Governance and Globalisation in the Gulf States", No. 24.

Bercovitch J. (1991), International Mediation, „Journal of Peace Research”, Vol. 28, No. 1.

Bercovitch J. 2009, Mediation and Conflict Resolution, w: The SAGE Handbook of Conflict Resolution, (eds.) J. Bercovitch, V. Kremenyuk, I. W. Zartman, London.

Bercovitch J., Wells R. (1993), Evaluating Mediation Strategies. A Theoretical and Empirical Analysis, „Peace \& Change”, Vol. 18, No. 1.

Bierzanek R. (1994), Regulacja sporów i konfliktów zbrojnych w stosunkach międzynarodowych, w: Stosunki międzynarodowe: geneza, struktura, funkcjonowanie, (red.) E. Haliżak, R. Kuźniar, Warszawa.

Bierzanek R., Symonides J. (2004), Prawo międzynarodowe publiczne, Warszawa.

Blanford N. (2006), A New Civil War in Lebanon?, „Time”, 5.12.2013.

Dagne T. (2011), Sudan: The Crisis in Darfur and Status of the North-South Peace Agreement, „Congressional Research Service", June 2011.

Darfur's Fragile Peace Agreement (2006), International Crisis Group, No. 39.

Dickinson E. (2013), Qatar builds a brand as mediator, „Christian Science Monitor”, http://www.csmonitor.com/World/Middle-East/2012/0328/Qatar-builds-a-brand-as-mediator.

Doha Agreement 2008, „On the Results of the Lebanese national Dialogue Conference”, http://peacemaker.un.org/sites/peacemaker.un.org/files/Lebanon_DohaAgreement2008_Engl.pdf (22.06.2013).

Doha Document for Peace 2011, http://unamid.unmissions.org/Portals/UNAMID/DDPD\%20English.pdf (15.09.13).

Eritrea-Djibouti Agreement 2010 - Agreement between the State of Eritrea and the Republic of Djibouti, http://awate.com/eritrea-djibouti-mediation-agreement-3/ (26.09.2013).

Executive Document of the Agreement 2010, http://awate.com/eritrea-djibouti-mediation-agreement-3/ (26.09.2013).

Fromherz A. J. (2012), Qatar: A Modern History, Padstow.

Góralczyk W., Sawicki S. (2009) Prawo międzynarodowe publiczne w zarysie, Warszawa. 
Hamidi A. (2009), Inscriptions of Violence in Northern Yemen: Haunting Histories, Unstable Moral Spaces, „Middle Eastern Studies”, Vol. 45, No. 2.

International Donor Conference for Reconstruction and Development in Darfur, http://www.darfurconference.com/Introduction (2.12.2013).

Kamrava M. (2011), Mediation and Qatari Foreign Policy, „Middle East Journal”, Vol. 65, No. 4.

Karta Narodów Zjednoczonych, San Francisco 1945 (1947), Dz. U., Nr 23, poz. 90.

Karzai in Doha: Qatar dominates role of peace mediator, „Middle East Online”, http://www.middle-east-online.com/english/?id=57824 (2.12.2013).

Khatib L. (2013), Qatar's foreign policy: the limits of pragmatism, „International Affairs”, Vol. 89, No. 2.

Kleiboer M. (1996), Understanding Success and Failure of International Mediation, „The Journal of Conflict Resolution", Vol. 40, No. 2.

Knio K. (2008), Is Political Stability Sustainable in Post- 'Cedar Revolution'Lebanon?, „Mediterranean Politics", Vol. 13, No. 3.

Lebanon-Constitution, http://www.servat.unibe.ch/icl/le00000_html (26.09.2013).

Madeyska D. (2008), Historia wspótczesna świata arabskiego, Warszawa.

Maritime Delimitation and Territorial Questions between Qatar and Bahrain. Merits. Judgment of 16 March 2001 (2001), I.C.J. Reports.

Ożarowski R. (2010), Szyicka rebelia w Jemenie (2004-2010) i jej implikacje dla regionu Bliskiego Wschodu, „Bliski Wschód: społeczeństwa - polityka - tradycje”, nr 7.

Peterson J. E. (2006), The al-Huthi Conflict in Yemen, „Arabian Peninsula Background Note”, No. ABPN-006.

Qatar to deploy troops between Djibouti and Eritrea, http://somalilandpress.com/qatar-to-deploy-troops-between-djibouti-and-eritrea-16208 (2.12.2013).

Qatar to mediate between Djibouti and Eritrea on border dispute (2010), „Sudan Tribune”, 9.06.2010, http://www.sudantribune.com/spip.php?article35327 (12.02.2014).

Rabi U. (2009), Qatar's Relations with Israel: Challenging Arab and Gulf Norms, „Middle East Journal", Vol. 63, No. 3.

Roberts D. B. (2009), Katar - w poszukiwaniu bezpieczeństwa, w: Państwo Katar: Gospodarka-Polityka - Kultura, (red.) K. Górak-Sosnowska, R. Czulda, Łódź.

Ryan C. (2012), The New Arab Cold War and the Struggle for Syria, „Middle East Report”, Vol. 42, http://www.merip.org/mer/mer262/new-arab-cold-war-struggle-syria (26.09.2013).

Salih K. O. (2008), The Internationalization of the Communal Conflict in Darfur and its Regional and Domestic Ramifications: 2001-2007, „Arab Studies Quarterly”, Vol. 30, No. 3.

Salmoni B. A., Loidolt B., Wells M. (2010), Regime and Periphery in Norhern Yemen, The Huthi Phenomenon, RAND, National Defence Research Institute, http://www.rand.org/content/dam/ rand/pubs/monographs/2010/RAND_MG962.pdf (26.09.2013).

Shields V. E. (2008), Political Reform in Lebanon: Has the Cedar Revolution Failed?, „The Journal of Legislative Studies", Vol. 14, No. 4.

Thousands attend Gemayel funeral (2006), http:/www.aljazeera.com/news/middleeast/2006/11/ 2008525142412197895.html (15.06.13).

Turek P. W. (2008), Dziwny sojusz Michela 'Auna z Hezbollahem i Amalem, „Między Wschodem a Zachodem. Łódzkie Studia Wschodoznawcze”, tom I.

Wiegand K. E. (2012), Bahrain, Qatar, and the Hawar Islands: Resolution of a Gulf Territorial Dispute, „Middle East Journal”, Vol. 66, No. 1. 
Wright S. (2009), Polityka zagraniczna Kataru: geopolityka i filary strategiczne, w: Państwo Katar: Gospodarka - Polityka - Kultura, (red.) K. Górak-Sosnowska, R. Czulda, Łódź.

\title{
STRESZCZENIE
}

Współcześnie na tle wysokiej konfliktogenności w regionie Bliskiego Wschodu i na kontynencie afrykańskim powiązanej z napięciami o charakterze religijno-etnicznym, proliferacją broni nuklearnej, czy rywalizacją mocarstw o wpływy, Katar i jego skuteczne działania na rzecz rozwiązywania sporów i konfliktów objawiają się jako regionalny fenomen XXI wieku. Katar pokazał jak należy wykorzystywać swój potencjał gospodarczy i polityczny, aby w okresie zaledwie kilku lat stać się regionalną siłą polityczną zdolną do efektywnego oddziaływania. Aby ukazać sposoby i efekty prowadzenia przez Katar mediacji wybrano trzy najbardziej reprezentatywne przykłady: sporu politycznego w Libanie, wojny w sudańskiej prowincji Darfur, konfliktu między rebeliantami a rządem w Jemenie. Zostały one uzupełnione o czwarty przykład, rzadko opisywany w kontekście mediacji katarskiej - spór pomiędzy Erytreą i Dżibuti, który też stanowi kolejny dowód na zwiększoną aktywność dyplomatyczną Kataru w Afryce. Mediacja jako dyplomatyczny instrument wpisuje się w strategię polityki zagranicznej Kataru. Strategia ta polega na tworzeniu „marki” państwa na arenie międzynarodowej, wzmacnianiu swojego bezpieczeństwa i stabilności oraz na kreowaniu własnej strefy wpływów.

\section{DIPLOMATIC ACTIVITIES OF QATAR IN DISPUTES AND CONFLICTS RESOLUTION IN THE MIDDLE EAST AND AFRICA}

\begin{abstract}
Currently, taking into consideration the high risk of outbreak of conflicts in the Middle East and Africa, what is connected with religious-ethnic tensions, nuclear power proliferation or superpowers' completion in order to establish its own influences, Qatar in its effective activities in conflict resolution appears as a regional phenomenon in the XXI century. Among the international community Qatar showed how to use its own economic and political potential to become regional political power. There are chosen four case studies of Qatari mediation in order to present means and effects of diplomatic conflict resolution: political crisis in Lebanon, war in Sudanese Darfur, conflict between rebels and government forces in Yemen and rarely exemplified in the context of Qatari mediation - Eritrea-Djibouti dispute. Mediation as a diplomatic means of conflict resolution is correlated with the strategy of foreign policy of Qatar. This strategy depends on making 'brand' of the state in the international relations, strengthen its own security and stability and expanding own sphere of influence.
\end{abstract}

